\title{
In vitro antimalarial activity of six Aspidosperma species from the state of Minas Gerais (Brazil)
}

\author{
MARIA FÂNI DOLABELA ${ }^{1,2,3}$, SALMA G. OLIVEIRA ${ }^{3}$, JOSÉ M. PERES ${ }^{3}$, \\ JOSÉ M.S. NASCIMENTO ${ }^{3}$, MARINETE M. PÓVOA ${ }^{3}$ and ALAIDE B. OLIVEIRA ${ }^{2}$ \\ ${ }^{1}$ Faculdade de Farmácia - ICS, Universidade Federal do Pará, \\ Cidade Universitária José da Silveira Neto, Bairro do Guamá, 68075-110 Belém, PA, Brasil \\ ${ }^{2}$ Departamento de Produtos Farmacêuticos, Faculdade de Farmácia, \\ Universidade Federal de Minas Gerais, Av. Antônio Carlos, 6627, Bairro Pampulha, 31270-901 Belo Horizonte, MG, Brasil \\ ${ }^{3}$ Laboratório de Malária, Seção de Parasitologia, Instituto Evandro Chagas, BR 316, Km 7 , \\ Bairro Levilândia, 67030-000 Ananindeua, PA, Brasil
}

Manuscript received on February 13, 2012; accepted for publication on June 1, 2012

\begin{abstract}
Ethnomedicinal informations point to some Aspidosperma species (Apocynaceae) as antimalarial plants in Brazil and have motivated the evaluation of six species which were collected in the state of Minas Gerais: A. cylindrocarpon Müll. Arg., A. parvifolium A. DC., A. olivaceum Müll. Arg., A. ramiflorum Müll. Arg., A. spruceanum Benth. ex Müll. Arg. and A. tomentosum Mart.. A total of 23 extracts of different plant parts in different solvents were assayed in vitro against chloroquine-resistant (W2) and chloroquine-sensitive (3D7) strains of Plasmodium falciparum. All the extracts were shown to be active with $\mathrm{IC}_{50}$ values in the range of $5.0 \pm 02.8 \mu \mathrm{g} / \mathrm{mL}$ to $65.0 \pm 4.2 \mu \mathrm{g} / \mathrm{mL}$. TLC profile of the extracts revealed the presence of alkaloids in the six species assayed. These results seem to confirm the popular use of Aspidosperma species to treat human malaria in Brazil and seem point to alkaloids as the putative active compounds of the assayed species.
\end{abstract}

Key words: antimalarial activity, Plasmodium falciparum, In vitro assays, Aspidosperma spp., Apocynaceae.

\section{INTRODUCTION}

Malaria is caused by protozoa of the genus Plasmodium and remains as one of the most serious parasitic diseases in the tropical and subtropical regions of the world because of its morbidity, mortality and drug resistance. It is estimated that 3.3 billion people were at risk of malaria in 2010, what represents approximately half of the world's population. There were 216 million cases of malaria

Correspondence to: Alaide Braga de Oliveira

E-mail: alaidebraga@terra.com.br and an estimated 655,000 deaths in 2010, and the disease was present in 106 countries and territories. However, the World Malaria Report 2011 has shown positive aspects in the fight against this disease: a decrease of more than $25 \%$ is reported in mortality rates, more than $25 \%$ globally since 2000 , and by $33 \%$ in the WHO African Region. (WHO 2011).

In Brazil, more than 350,000 cases were reported annually for the period of 2001-2007, with a maximum of 607,730 cases, in 2005 . A decrease of approximately $25 \%$ in the number of reported cases 
was recorded since 2006, what is considered as a consequence of public actions related to vigilance, prevention and control. The majority (97\%) of the reported cases occur in the Legal Amazon Region and is mostly caused by $P$. vivax. However, it causes concern the information that, in 2009 and 2010, approximately $16 \%$ of the confirmed cases were by $P$. falciparum, the most deadly Plasmodium species, (MS 2008, WHO 2011).

Quninine, the first drug used in malaria chemotherapy, was isolated in 1820 , by the French scientists Pelletier and Caventou, from the bark of Cinchona species (Rubiaceae) which were used by Peruvian Indians, in South America and whose plant material were taken to Europe by Jesuits, in the XVII century. The structure of quinine was established by Rabe in 1908, and its synthesis was accomplished in 1944 by Woodward and Doering (Figure 1). However, its synthetic production by industrial means is both complex and costly. Quinine is still used today, and it is currently obtained by extraction from Cinchona spp, which grow wild in South America and are cultivated in Java (Boulos et al. 1997).

Chloroquine(CQ), asynthetic4-aminoquinoline developed in the 1940's, represents the most widely used antimalarial drug. However, since the 60's, its effectiveness declined at an accelerating rate, as consequence of the resistance of $P$. falciparum strains which, associated with the resistance of the parasites vectors (Anopheles, Culicideae) to inseticides, resulted into significative increase in malaria-related morbidity and mortality. Mefloquine, as quinine, is a 4-quinolinomethanol, but totally synthetic, and was introduced in 1985 (Figure 1). (Guerin et al. 2002, Fidock et al. 2004).

Presently, artemisinin, the active compound from the traditional Chinese drug Artemisia апnиа (Asteraceae), and its semi-synthetic derivatives artemether, artether and artesunate are the most used drugs in malaria therapeutics. However artemisinin based monotherapy represents a risk for the development of resistance to this drug what led to its withdrawal from the market. Indeed, resistance of $P$. falciparum to artemisinin was confirmed at Cambodia-Thailand border in 2009. (WHO 2010).

Artemisinin-based Combination Therapy ACTs are recommended and five pharmaceutical formulations are presently marketed. One is based on artemether (artemether-lumefantrine), and all the others are based on artesunate in combination with amodiaquine (2 formulations), mefloquine (one formulation) and one with sulfadoxine + pyrimethamine(WHO 2009) (Figure 1). Atovaquone, the last antimalarial drug introduced in clinics, is a totally synthetic naphthoquinone (Baggish and Hill 2002). In this case, the contribution of natural products was also important once atovaquone was developed after an active natural product as template: the prenylnaphthoquinone lapachol, present mainly in species of the genus Tabebuia (Bignoniaceae) which occur in many Southamerican countries (Castellanos et al. 2009, Wagner and Seitz 1998). Atovaquone-proguanil (Malarone ${ }^{\circledR}$ ) is one of the non-artemisinin combination therapies in clinical use (WHO 2008). Structures of naturally occurring antimalarial drugs and the synthetic derived ones cited here are shown on Figure 1.

The quest of new antimalarial drugs is needed and the investigation of plants traditionally and/ or popularly used to treat malaria is considered a valuable strategy (Ginsburg and Deharo 2011, Bourdy et al. 2007, Wright 2005). Two approaches can be explored: one is focused on the search of naturally occurring bioactive compounds, potential new drugs or templates, and the second one aims at the validation of traditionally used plant remedies which could lead to the development of effective and safe phytomedicines. In the second approach, identification of active compounds is necessary to be used as biomarkers in the standardization of extracts that must be submitted to pre-clinical and clinical studies to guarantee the standard quality required for phytomedicines (Oliveira et al. 2009a, Wagner 2004). 


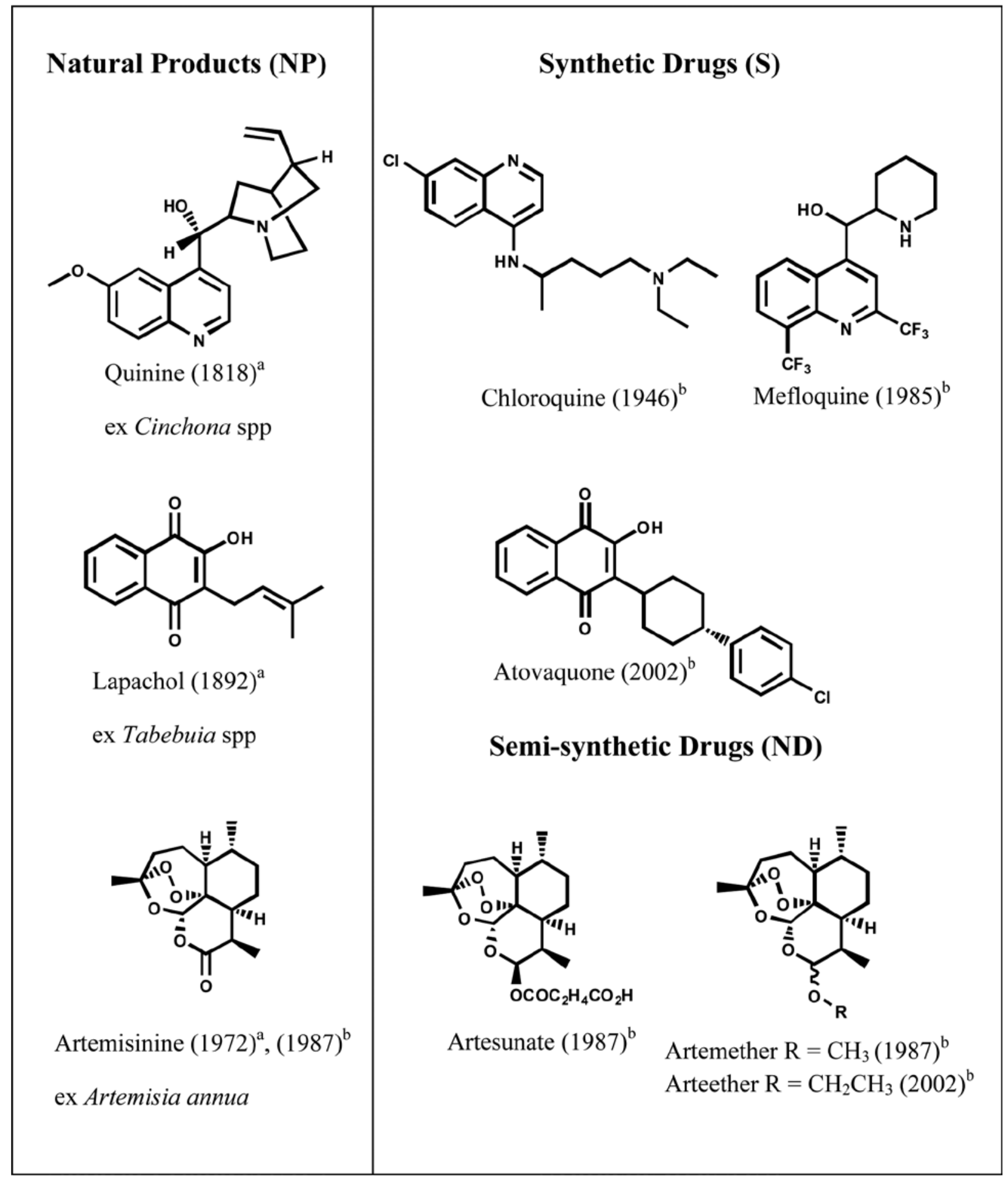

${ }^{\mathbf{a}}$ : Year of isolation; ${ }^{\mathbf{b}}$ : Year of introduction in therapeutics; NP: Natural Products; $\mathbf{S}^{*}$ : Synthtetic drug derived after a natural product as template, ND: Natural Product derivatives.

Figure 1 - Plant-derived antimalarial drugs: natural products (NP), synthetic drugs (S) and semi-synthetic drugs (ND, Natural Derivatives). 
The first step in the investigation of a traditionally and/or popularly used plant for treatment of human malaria aiming at the isolation of antimalarial compounds is the in vitro evaluation of its extracts against cultures of $P$. falciparum strains in human erythrocytes. This is the most recommended methodology although other approaches are available. (Oliveira et al. 2009a, Fidock et al. 2004). Once the in vitro activity is confirmed, extracts with $\mathrm{IC}_{50} \leq 50$ $\mu \mathrm{g} / \mathrm{mL}$ deserve further investigation for isolation of antiplasmodial compounds (Oliveira et al. 2009a).

Aspidosperma Mart. \& Zucc. (tribo Plumeriae) is found from Mexico to Argentina (MarcondesFerreira Neto 1988). This genus belongs to the Apocynaceae family and includes 24 species that have been traditionally used for the treatment of human malaria in Brazil and other South American countries. (Brandão et al. 1992, Milliken and Albert 1996, 1997, Bertani et al. 2005, Mariath et al. 2009).

Chemically, Aspidosperma species are characterized by the presence of alkaloids. Plants of this genus have afforded more than two hundred indolomonoterpenoid alkaloids, mainly in the period between 1965 and 1980. (Pereira et al. 2007). However, there are relatively few reports on the biological activities of these alkaloids (Oliveira et al. 2009a, b). A relevant one is elliptinium acetate, an antitumoral drug (Celliptium ${ }^{\circledR}$ ) that was developed from ellipticine, a pyridocarbazol alkaloid originally isolated from Ochrosia elliptica (Australian evergreen shrub), and that occurs in other Apocynaceae genera such as Aspidosperma (Cragg and Newman 2005).

Extracts from various Aspidosperma species were evaluated for other biologica/pharmacological activities. A. ramiflorum and A. olivaceum were assayed against bacteria, fungi and yeasts when stems and leaves extracts from $A$. ramiflorum showed weak antifungal activity against Cladosporium cladosporioides and C. sphaerospermum. Inhibition of bacteria growth was observed in cultures of Escherichia coli (Agripino et al. 2004). A methanol extract from $A$. ramiflorum stem bark disclosed moderate antibacterial activity against Bacillus subtilis and Staphylococcus aureus. Subfractions of this extract showed moderate to high activity against these bacteria as well as to E. coli, and Pseudomnas aeruginosa. Two alkaloids, ramiflorines $\mathrm{A}$ and $\mathrm{B}$, were isolated from $A$. ramiflorum and were identified as responsible for its bactericidal effect (Tanaka et al. 2006).

An alkaloidal extract from $A$. ramiflorum, rich in ramiflorines $\mathrm{A}$ and $\mathrm{B}$, showed activity against promastigotes of Leishmannia $(V$.) braziliensis and L. (L.) amazonensis (Ferreira et al. 2004). Subsequently, ramiflorines $\mathrm{A}$ and $\mathrm{B}$ were isolated from an $A$. ramiflorum alkaloidal extract and were submitted to further assays against promastigotes of L. (L.) amazonensis, confirming the antileishmanial effect (Tanaka et al. 2007).

An ethanol extract from A. polyneuron roots exhibited antifungal activity against Cladosporium herbarium. However the substance responsible for this activity was not identified (Ferreira et al. 2003). Activity against Proteus mirabilis was observed for an ethanol extract from A. polyneuron that is rich in alkaloids (Granato et al. 2005).

A pro-erectile effect was observed in mice treated with fractions derived from an ethanol extract from A. ulei bark (Campos et al. 2006) and a bark extract from $A$. quebracho blanco was able to stimulate human receptors related to penile erection (Sperling et al. 2002). These two extracts were rich in alkaloids.

A. nitidum is used in the Amazon region as antiinflamatory as well as for treatment of fevers and malaria. An ethanol extract from the trunkwood disclosed anti-inflammatory and antinociceptive activities and afforded the following substances: a mixture of $\beta$-sitosterol and stigmasterol, pentacyclic triterpenes ( $\beta$-amyrin and lupeol), an inositol (L-2O-methyl-4 chiroinositol) and a $\beta$-carboline alkaloid (harman-3-carboxilic acid) (Pereira et al. 2006).

Up to now, crude extracts and/or alkaloidal fractions from 11 Aspidosperma species have been evaluated for antimalarial activity: $A$. excelsum 
(Kvist et al. 2006, Brandão et al. 1992, Carvalho et al. 1991), A. macrocarpon (Mesquita et al. 2007), A. megalocarpon (Weniger et al. 2001), A. nitidum (Becker 1949, Brandão et al. 1992, Carvalho et al. 1991), A. oblongum (Cabral et al. 1993), A. olivaceum (Brandão et al. 1985), A. polyneuron (Wasicky et al. 1942), A. pyrifolium (Bourdy et al. 2004, Weniger et al. 2001), A. quebracho-blanco (Bourdy et al. 2004, Mariath et al. 2009), A. ramiflorum (Krettli et al. 2008), and $A$. rigidum (Kvist et al. 2006).

Only 14, among hundreds of known alkaloids from Aspidosperma were tested: two were isolated from $A$. desmanthum and A. vargasii (AndradeNeto et al. 2007), 11 other ones were previously obtained from A. megalocarpon and A. pyrifolium (Mitaine-Offer et al. 2002) and one from $A$. parvifolium (Oliveira et al. 2010).

We report here the evaluation of the antiplasmodial activity of extracts from six Aspidosperma species with reputation of use to treat malaria or fever in different regions of Brazil.

\section{MATERIALS AND METHODS}

Plant MATERIAL

Plant material from A. parvifolium was collected in the municipality of Paracatú, state of Minas Gerais, and all the others were collected in the Pampulha Campus of the Universidade Federal de Minas Gerais - UFMG, Belo Horizonte, Minas Gerais, Brazil. Dr. J. A Lombardi has done the taxonomical identification of the species (present address: Departamento de Botânica, Instituto de Biociências de Rio Claro,UNESP, Av. 24-A 1515,CEP 13506900, Rio Claro, SP, Brazil). Voucher specimens are deposited in the BHCB, UFMG and the code numbers are shown in Table I.

\section{EXTRACTION}

The different plant parts were separated, dried in an oven with circulating air at $40^{\circ} \mathrm{C}$ and milled. Powdered plant materials were extracted by percolation with ETOH $96{ }^{\circ} \mathrm{GL}$ and/or by Soxhlet extraction successively with dichloromethane and ETOH after addition of 5\% ammonium hydroxide to the powdered plant material $(\mathrm{v} / \mathrm{w})$. Extracts were concentrated in a rotavapor to give the crude dry extracts whose phytochemical profiles were analysed by TLC (Table I).

ANTIPLASMODIAL ASSAY

P. falciparum clones (W2 and 3D7) were kept in continuous cultures in human erythrocytes suspended in RPMI 1640 suplemented with $10 \%$ human serum, using the candle jar/Petri dish method as described by Trager and Jensen (1976). The antiplasmodial effects of the extracts and controls were determined according to the microscopic methodology (Rieckmann et al. 1978) with minor modifications. (Carvalho et al.1991). Briefly, a suspension of ring-stage parasites in sorbitol-synchronized blood cultures $(100 \mu \mathrm{L})$ containing predominantly trophozoits was added to $96-$-well culture plates at $1 \%$ parasitemia and $2.5 \%$ hematocrit and then incubated with the test samples in various concentrations for a total of $72 \mathrm{~h}$, at $37{ }^{\circ} \mathrm{C}$. Negative control of parasite culture and positive control in which chloroquine and mefloquine were added to the parasite culture were run simultaneously. Stock solution of the test samples in DMSO $(10 \mathrm{mg} / \mathrm{mL})$ were diluted in complete medium to a final concentration of $0.002 \%(\mathrm{v} / \mathrm{v})$ and stored at $-20^{\circ} \mathrm{C}$. After $24 \mathrm{~h}$ and $48 \mathrm{~h}$ incubation periods. The culture medium was replaced with fresh medium with or without test samples/control drugs. After further $24 \mathrm{~h}$ incubation, Giemsa stained smears were microscopically examined to determine the parasitemia by counting 5,000 erytrocites. All experiments were performed three times, and each sample was tested in triplicate. The results were expressed as the means $\mathrm{IC}_{50}$ and $\mathrm{IC}_{90}$ and the Graph Pad Prism 4.0 program was used to statiscally compare the inhibition of the two different $P$. falciparum clones. 


\section{CYTOTOXICITY ASSAY}

Vero cells were exposed to different concentrations of extracts for 48 and $72 \mathrm{~h}$. After incubation, cell viability was assessed by the MTT assay (Merck solution $2 \mathrm{mg} / \mathrm{mL}^{-1}$ in PBS) (Twentyman and Luscombe 1987). Each sample was assayed in four replicates for concentrations ranging from 500 to $0.125 \mu \mathrm{g} / \mathrm{mL}$. The cytotoxicity of each sample was expressed as $\mathrm{CC}_{50}$, i.e. the concentration of sample that inhibited cell growth by $50 \%$.

\section{RESULTS AND DISCUSSION}

The six species we had assayed, $A$. cylindrocarpon Müll. Arg., A. parvifolium A. DC., A. olivaceum Müll.Arg., A. ramiflorum Müll.Arg., A. spruceanum Benth. ex Müll. Arg. and A. tomentosum Mart., were phytochemically investigated previously and the isolation of indolomonoterpenoid alkaloids was described for all of them (for a review see Pereira et al. 2007).

A total of 23 extracts were obtained from different parts of the six Aspidosperma species. Powdered dry plant materials were extracted by two different methodologies: 1) percolation with ethanol $96{ }^{\circ} \mathrm{GL}$, and 2) Soxhlet extractions with dichloromethane followed by ethanol $96{ }^{\circ} \mathrm{GL}$ of the powdered plant material to which ammonium hydroxide had been added. Data on collection sites, popular names, code number of voucher specimens and classes of natural products detected by TLC phytochemical screening are shown in Table I. As expected, alkaloids were detected in all the six species by TLC analysis.

TABLE I

Data on collection sites, local names, voucher specimens, plant parts extracted, extraction, phytochemical screening by TLC of the Aspidosperma species extracts (Apocynaceae).

\begin{tabular}{|c|c|c|c|c|c|}
\hline $\begin{array}{l}\text { Aspidosperma } \\
\text { species }\end{array}$ & $\begin{array}{l}\text { Collection } \\
\text { sites }\end{array}$ & $\begin{array}{c}\text { Local names } \\
\text { (Lorenzi 1992, Pio Correa 1978) }\end{array}$ & $\begin{array}{l}\text { Voucher } \\
\text { numbers }\end{array}$ & $\begin{array}{c}\text { Extraction } \\
\text { Solvent/method/plant part }\end{array}$ & $\begin{array}{l}\text { NP Classes (TLC) } \\
\text { Wagner } 2004\end{array}$ \\
\hline $\begin{array}{l}\text { A.cylindrocarpon } \\
\text { Müll. Arg. }\end{array}$ & BH/UFMG & $\begin{array}{l}\text { peroba-de Minas, peroba-rosa, } \\
\text { peroba-iquira }\end{array}$ & BHCB47812 & ETOH-P-Tr & $\mathrm{A}, \mathrm{F}, \mathrm{T}, \mathrm{St}, \mathrm{Sa}$ \\
\hline \multirow{7}{*}{$\begin{array}{l}\text { A. olivaceum } \\
\text { Müll. Arg. }\end{array}$} & BH/UFMG & $\begin{array}{l}\text { guatambú-marfim, pequiá- } \\
\text { marfim, pequiá-branco }\end{array}$ & & DCM-S-L & $\mathrm{T}, \mathrm{St}, \mathrm{Sa}$ \\
\hline & & & & ETOH-S-L & $\mathrm{T}, \mathrm{St}$ \\
\hline & & & & ETOH-P-Tr & $\mathrm{F}, \mathrm{T}, \mathrm{St}$ \\
\hline & & & & DCM-S-Tr & $\mathrm{A}, \mathrm{Sa}$ \\
\hline & & & & ETOH-S-Tr & $\mathrm{T}, \mathrm{St}, \mathrm{Sa}$ \\
\hline & & & & DCM-S-B & $\mathrm{A}, \mathrm{S}$ e $\mathrm{F}$ \\
\hline & & & & ETOH-S-B & $\mathrm{A}, \mathrm{Sa}, \mathrm{F}$ \\
\hline \multirow{8}{*}{$\begin{array}{l}\text { A. ramiflorum } \\
\text { Müll. Arg. }\end{array}$} & BH-UFMG & $\begin{array}{l}\text { matambú, guatambú, guatambú- } \\
\text { amarelo, pequiá-doce, pequiá }\end{array}$ & BHCB848 & ETOH-P-L & $\mathrm{A}, \mathrm{Sa}, \mathrm{T}, \mathrm{St}, \mathrm{F}$ \\
\hline & & & & DCM-S-L & $\mathrm{A}, \mathrm{Sa}, \mathrm{T}, \mathrm{St}, \mathrm{F}$ \\
\hline & & & & ETOH- S-L & $\mathrm{A}, \mathrm{Sa}, \mathrm{T}, \mathrm{St}, \mathrm{F}$ \\
\hline & & & & ETOH-P-Tr & $\mathrm{A}, \mathrm{F}$ \\
\hline & & & & DCM-S-Tr & $\mathrm{A}, \mathrm{Sa}, \mathrm{T}, \mathrm{St}, \mathrm{F}$ \\
\hline & & & & ETOH-S-Tr & A \\
\hline & & & & DCM- S-B & $\mathrm{A}, \mathrm{Sa}, \mathrm{T}, \mathrm{St}, \mathrm{F}$ \\
\hline & & & & ETOH-S-B & $\mathrm{A}, \mathrm{F}$ \\
\hline $\begin{array}{c}\text { A. parvifolium } \\
\text { A. DC }\end{array}$ & Paracatú & $\begin{array}{l}\text { guatambú, guatambú-branco, } \\
\text { pequiá-marfim, peroba, } \\
\text { paupereira, tambú }\end{array}$ & BHCB60345 & ETOH-P-B & $\mathrm{A}, \mathrm{F}, \mathrm{T}, \mathrm{St}, \mathrm{Sa}$ \\
\hline
\end{tabular}


TABLE I (continuation)

\begin{tabular}{|c|c|c|c|c|c|}
\hline \multirow{8}{*}{$\begin{array}{c}\text { A spruceanum } \\
\text { Benth. ex Müll. } \\
\text { Arg. }\end{array}$} & BH-UFMG & $\begin{array}{l}\text { amargoso, peroba, guatambú-rugoso, } \\
\text { quina-da-mata, pequiá-marfim }\end{array}$ & BHCB46274 & ETOH-P-L & $\mathrm{F}, \mathrm{Sa}, \mathrm{T}, \mathrm{St}$ \\
\hline & & & & DCM- S-L & $\mathrm{Sa}, \mathrm{T}, \mathrm{St}$ \\
\hline & & & & ETOH- S-L & $\mathrm{F}, \mathrm{T}, \mathrm{St}, \mathrm{Sa}$ \\
\hline & & & & DCM- S-Tr & $\mathrm{A}, \mathrm{Sa}, \mathrm{T}, \mathrm{St}$ \\
\hline & & & & ETOH-S-Tr & $\mathrm{A}, \mathrm{Sa}$ \\
\hline & & & & ETOH-P-Tr & $\mathrm{A}, \mathrm{Sa}, \mathrm{T}, \mathrm{St}$ \\
\hline & & & & DCM- S-Tr & $\mathrm{A}, \mathrm{As}, \mathrm{T}, \mathrm{St}$ \\
\hline & & & & ETOH-S-Tr & $\mathrm{A}, \mathrm{As}, \mathrm{T}, \mathrm{St}$ \\
\hline \multirow{4}{*}{$\begin{array}{l}\text { A. tomentosum } \\
\text { Mart. }\end{array}$} & & $\begin{array}{l}\text { pau-pereira-do-campo, pereiro-do-campo, } \\
\text { peroba-do-campo, peroba-do-cerrado }\end{array}$ & BHCB49751 & ETOH-P-Tr & $\mathrm{A}, \mathrm{T}, \mathrm{St}, \mathrm{F}$ \\
\hline & & & & ETOH-P-L & F, Sa, T, St, F \\
\hline & & & & ETOH-P-F & $\mathrm{A}, \mathrm{Sa}, \mathrm{T}, \mathrm{St}, \mathrm{F}$ \\
\hline & & & & ETOH-P-Se & $\mathrm{A}, \mathrm{Sa}, \mathrm{T}, \mathrm{St}$ \\
\hline
\end{tabular}

BH: Belo Horizonte, B: trunk bark; F: fruits, L: leaves; Tr: trunk wood; Se: seeds; P: percolation; S: Soxhlet; NP: natural products, A: alkaloids; T: triterpenes; St: steroids; F: flavonoids; Sa: saponins.

In vitro assays were carried out by the microspic method (Rieckmann et al. 1978) with minor modifications (Carvalho et al. 1991). Extracts were assayed against chloroquine-resistant (CQR, W2) and sensitive (CQS, 3D7) clones of P. falciparum and all of them had shown to be active disclosing $\mathrm{IC}_{50}$ values in the range of $5.0 \pm 02.8 \mu \mathrm{g} / \mathrm{mL}$ to $65.0 \pm 4.2 \mu \mathrm{g} / \mathrm{mL}$ (Table II).

It is usually considered that extracts showing $\mathrm{IC}_{50} \leq 50 \mu \mathrm{g} / \mathrm{mL}$ deserve further investigations for the isolation and identification of active compound(s). All the extracts, except that one from A. spruceanum leaves (EtOH-P-L, W2 $\mathrm{IC}_{50}=$ $\left.65.0+4.2,3 \mathrm{D} 7 \mathrm{IC}_{50}>100,3 \mathrm{D} 7\right)$, fall in this group (Table II).

For 9 of the 23 extracts, the $\mathrm{IC}_{50}$ values are lower than $10 \mu \mathrm{g} / \mathrm{mL}$ and they can be considered as very active: five extracts from A. olivaceum (DCMS-L, ETOH- S-L, DCM-S-Tr, DCM-S-B, ETOH$\mathrm{S}-\mathrm{B}$ ), two from $A$. ramiflorum (DCM-S-L and DCM- S-B) and two from A. spruceanum (DCMS-Tr and DCM-S-B). Interestingly, all these extracts were obtained by the traditional Soxhlet extraction method of the alkalinized powdered plant material, leading to a more selective extraction once, in this condition, acidic compounds (carboxylic acids and phenols) are in their salt forms and, therefore, are not extracted resulting in a selective extraction of alkaloids along with neutral compounds.

Concerning the susceptibility towards the $P$. falciparum clones, 10 out of the 23 extracts showed no significant difference against $\mathrm{CQR}$ and $\mathrm{CQS}$ P. falciparum clones: one from $A$. cylindrocarpon (ETOH-P-Tr), four from A. olivaceum (ETOHS-L, DCM-S-Tr, DCM-S-B, ETOH-S-B), two from A. ramiflorum (DCM-S-L, DCM-S-B), one from A. spruceanum (DCM- S-Tr) and two from A. tomentosum (ETOH-P-Tr and ETOH-P-L). Seven of the extracts were more active in the CQS (3D7) clone than in the CQR (W2) clone and the difference in the IC50 values is higher for those of A. ramiflorum ETOH-S-Tr (3D7 $0.98 \pm 0.03 \mu \mathrm{g} /$ $\mathrm{mL}$ vs W2 $19.75 \pm 0.35 \mu \mathrm{g} / \mathrm{mL}$ ) and $A$. tomentosum ETOH-P-Se (3D7 $3.03 \pm 0.20 \mu \mathrm{g} / \mathrm{mL}$ vs W2 $24.51 \pm 3.56 \mu \mathrm{g} / \mathrm{mL}$ ). Nine of the extracts were more active in the CQR (W2) clone and a higher difference was observed for the DCM leaves $A$. olivaceum extract (DCM-S-L) which was prepared 
TABLE II

In vitro antimalarial activity of the six Aspidosperma species extracts against Plasmodium falciparum (W2/CQR, 3D7/CQS clones) and cytotoxicity in Vero cells cultures.

\begin{tabular}{|c|c|c|c|c|c|}
\hline \multirow{2}{*}{ Species Extracts } & \multicolumn{2}{|c|}{ W2 } & \multicolumn{2}{|c|}{ 3D7 } & \multirow{2}{*}{$\begin{array}{l}\text { Vero cells } \\
\mathrm{CC}_{50}(\mu \mathrm{g} / \mathrm{ml})\end{array}$} \\
\hline & $\mathrm{IC}_{50}(\mu \mathrm{g} / \mathrm{ml}) \pm \mathrm{SD}$ & $\mathrm{IC}_{90}(\mu \mathrm{g} / \mathrm{ml}) \pm \mathrm{SD}$ & $\mathrm{IC}_{50}(\mu \mathrm{g} / \mathrm{ml}) \pm \mathrm{SD}$ & $\mathrm{IC}_{90}(\mu \mathrm{g} / \mathrm{ml}) \pm \mathrm{SD}$ & \\
\hline \multicolumn{6}{|c|}{ Aspidosperma cylindrocarpon } \\
\hline ETOH-P-Tr & $44.0 \pm 6.36$ & $104.5 \pm 6.362 .3$ & $39.0 \pm 2.83$ & $89.0 \pm 7.072 .3$ & $>500$ \\
\hline \multicolumn{6}{|l|}{ A. olivaceum } \\
\hline DCM-S-L & $7.0 \pm 0,2$ & $23,0 \pm 0.23 .2$ & $25.5 \pm 2.12$ & $49.5 \pm 6.31 .9$ & $>500$ \\
\hline ETOH- S-L & $7.0 \pm 0.71$ & $26.5 \pm 0,713.8$ & $5.0 \pm 2.80$ & $24.5 \pm 2.10-4.9$ & ND \\
\hline DCM-S-Tr & $<6$ & ND & $<6$ & ND & $>500$ \\
\hline DCM-S-B & $<6$ & ND & $<6$ & ND & \\
\hline ETOH-S-B & $5.0 \pm 2.8$ & $24.5 \pm 2.84 .9$ & $7.0 \pm 0.42$ & $26.5 \pm 0.713 .8$ & $>500$ \\
\hline \multicolumn{6}{|l|}{ A. parvifolium } \\
\hline ЕTOH-P-B & $32.75 \pm 1.06$ & $74.50 \pm 1.342 .3$ & $20.51 \pm 0.70$ & $38.00 \pm 4.261 .8$ & $>500$ \\
\hline \multicolumn{6}{|l|}{ A. ramiflorum } \\
\hline ETOH-P-L & $32.8 \pm 1.13$ & $61.75 \pm 1.131 .8$ & $20.5 \pm 0.71$ & $60.5 \pm 0.713 .0$ & ND \\
\hline DCM-S-L & $<6$ & ND & $<6$ & ND & ND \\
\hline ETOH-P-Tr & $36.5 \pm 0.20$ & $100.0 \pm 0.202 .7$ & $48.0 \pm 1.1$ & $103.0 \pm 1.42 .1$ & ND \\
\hline DCM-S-Tr & ND & ND & $9.5 \pm 1.41$ & $27.0 \pm 1.412 .8$ & $>500$ \\
\hline ETOH-S - Tr & $19.75 \pm 0.35$ & $30.75 \pm 0.351 .5$ & $0.98 \pm 0.03$ & $16.0 \pm 2.816$ & ND \\
\hline DCM- S-B & $<6$ & ND & $<6$ & ND & $>500$ \\
\hline \multicolumn{6}{|l|}{ A. spruceanum } \\
\hline ETOH-P-L & $65.0 \pm 4.2$ & $107.8 \pm 0.711 .6$ & $>100$ & ND & ND \\
\hline DCM- S-L & $23.25 \pm 0.35$ & $47.0 \pm 2.832 .0$ & $35.0 \pm 4.2$ & $63.5 \pm 0.71 .8$ & ND \\
\hline ETOH- P-Tr & $29.52 \pm 0.71$ & ND & $41.5 \pm 2.12$ & $101.5 \pm 9.12 .4$ & ND \\
\hline DCM- S-Tr & $<6.0$ & ND & $<6.0$ & ND & 109,6 \\
\hline CLOR-P-Tr & $37.0 \pm 7.1$ & $102.0 \pm 2.82 .8$ & $>100$ & ND & $\mathrm{ND}$ \\
\hline ETOH-P-B & $26.25 \pm 4.07$ & $48.50 \pm 3.181 .8$ & $14.0 \pm 4.2$ & $30,0 \pm 2,832.1$ & ND \\
\hline DCM- S-B & $<6.0$ & ND & $15.75 \pm 1.76$ & $28.5 \pm 0.711 .8$ & ND \\
\hline ETOH-S-B & $28.01 \pm 3.51$ & $52.03 \pm 2.831 .8$ & $19.0 \pm 2.83$ & $50.5 \pm 2.122 .6$ & ND \\
\hline \multicolumn{6}{|l|}{ A. tomentosum } \\
\hline ETOH-P-Tr & $26.50 \pm 3.50$ & $54.75 \pm 1.092 .0$ & $25.00 \pm 4.24$ & $61.00 \pm 4.242 .4$ & ND \\
\hline ETOH-P-L & $23.75 \pm 1.06$ & $54.75 \pm 1.092 .0$ & $27.00 \pm 5.66$ & $47.00 \pm 5.661 .7$ & ND \\
\hline ETOH-P-F & $20.52 \pm 1.41$ & $37.53 \pm 0.711 .8$ & $38.55 \pm 1.06$ & $99.54 \pm 4.952 .5$ & ND \\
\hline ETOH-P-Se & $24.51 \pm 3.56$ & $54.75 \pm 1.092 .2$ & $3.03 \pm 0.20$ & $27.03 \pm 0.209 .01 .5$ & $>500$ \\
\hline \multicolumn{6}{|l|}{ Positive controls } \\
\hline Chloroquine & $0.02 \pm 0.002$ & ND & $0.0013 \pm 0.0001$ & $0.0020 \pm 0.00011 .5$ & ND \\
\hline Mefloquine & $0.0165 \pm 0.002$ & $0.0895 \pm 0.02$ & $0.048 \pm 0.0007$ & $0.0975 \pm 0.00072 .0$ & ND \\
\hline
\end{tabular}

CQR: chloroquine-resistant, CQS: chloroquine-sensitive, SD: Standar Deviation, ETOH: ethanol, DCM: dichloromethane, P: percolation, S: Soxhlet extraction, B: trunk bark, F: fruits, $\mathbf{L}$ : leaves; Tr: trunk wood; Se: seeds; IC $_{\mathbf{5 0}}: 50 \%$ inhibitory concentration, $\mathbf{I C}_{\mathbf{9 0}}$ : $90 \%$ inhibitory concentration, $\mathbf{C C}_{\mathbf{5 0}}: 50 \%$ cytotoxic concentration; ND: Not determined. 
by Soxhlet extraction of alkalinized plant material and was approximately 3 times more potent against the W2 strain (IC50 $7.0 \pm 0.71 \mu \mathrm{g} / \mathrm{mL}$ ) than against the 3D7 strain $\left(\mathrm{IC}_{50} 25.5 \pm 2.12 \mu \mathrm{g} / \mathrm{mL}\right)$. Surprisingly, this extract did not show alkaloids on TLC, an indicative that the active compound(s) do(es) not belong to this natural product class. Besides, as mentioned, A. olivaceum was tested previously and negative results were reported for EtOH and Hexane-AcOEt extracts in assays in $P$. berghei infected mice. There is no information on the plant part used. (Brandão et al. 1985). Recently, the antimalarial activity of $A$. ramiflorum was reported in vitro against $P$. falciparum $\mathrm{W} 2$ clone ( $\mathrm{IC}_{50} 11$ to $40 \mu \mathrm{g} / \mathrm{mL}$ ). In vivo tests with $P$. berghei NK65 in mice showed that the crude extract and total alkaloids were partially active at $500 \mathrm{mg} / \mathrm{kg}$ and $250 \mathrm{mg} / \mathrm{kg}$, respectively (Krettli et al. 2008).

The $\mathrm{IC}_{90} / \mathrm{IC}_{50}$ ratios of the extracts towards both of the P. falciparum clones (W2 and 3D7) are in the range of 16.0 to 1.5 and for the antimalarial drugs chloroquine and mefloquine the ratios are 1.5 and 2.0, respectively. For six of the 23 extracts assayed ratios $>2.0$ were calculated for each of the $P$. falciparum clones what allows one to infer that these extracts might be the most promising ones, particularly those related to the CQR clone: A. ramiflorum (ETOH-P-L and ETOH-S -Tr), $A$. spruceanum (ETOH-P-L, ETOH-P-B and ETOH$\mathrm{S}-\mathrm{B}$ ) and $A$. tomentosum (ETOH-P-F).

The cytotoxicity of some of the 23 extracts was assessed in Vero cells culture by the MTT assay (Twentyman and Luscombe 1987) and no cytotoxic effect was observed up to the concentration of 500 $\mu \mathrm{g} / \mathrm{mL}$, except for A. spruceanum dichloromethane trunkwood extract (DCM-S-Tr) which was moderately cytotoxic $\left(\mathrm{CC}_{50}=109.6 \mu \mathrm{g} / \mathrm{mL}\right)$ (Table III). The Selectivity Index ( $\mathrm{SI}=\mathrm{CC}_{50}$ l $\mathrm{IC}_{50}$ ) was calculated for some of the extracts and values higher than 10 were observed disclosing the potential of these species as sources of antimalarial compounds. (Table III).

TABLE III

Selectivity index (SI) for some Aspidosperma species extracts which have been assayed for antiplasmodial activity (W2/CQR, 3D7/CQS) and cytotoxicity in Vero cells culture.

\begin{tabular}{c|c|c|c|c}
\hline Aspidosperma species & Extracts & $\mathrm{CC}_{50}(\mu \mathrm{g} / \mathrm{ml})($ Vero cells $)$ & SI $(\mathrm{W} 2)$ & SI $(3 \mathrm{D} 7)$ \\
\hline \multirow{2}{*}{ A. cylindrocarpon } & ETOH-P-Ca-L & $>500$ & $>11.36$ & $>12.82$ \\
\hline \multirow{2}{*}{ A. olivaceum } & DCM-S-L & $>500$ & $>71.43$ & $>19.61$ \\
\cline { 2 - 5 } & DCM-S-B & $>500$ & $>83.33$ & $>83.33$ \\
\cline { 2 - 5 } A. parvifolium & ETOH-S-B & $>500$ & $>100,00$ & $>71.43$ \\
\hline \multirow{2}{*}{ A. ramiflorum } & EtOH-P-B & $>500$ & ND & $>24.38$ \\
\cline { 2 - 5 } & DCM-S-L & $>500$ & $>83,33$ & $>52.63$ \\
\hline A. spruceanum & DCM-S-Tr & $>500$ & 18.27 & $>83.33$ \\
\hline A. tomentosum & DCM-S-Tr & 109.6 & $>20.4$ & $>18.27$ \\
\hline
\end{tabular}

$\mathbf{C C}_{\mathbf{5 0}}$ : 50\% Cytotoxic Concentration; W2: P. falciparum clone resistant to chloroquine and sensitive to mefloquine; 3D7: $P$. falciparum clone sensitive to chloroquine; SI: Selectivity Index; DCM-S L: Leaves EtOH extract prepared in Soxhlet; ETOH-S L: Leaves EtOH extract prepared in Soxhlet; ETOH-P-TR: Trunk wood EtOH extract obtained by percolation; DCM-S-Tr: Trunk wood DCM extract obtained in Soxhlet; DCM-S-B: Trunk bark DCM extract obtained in Soxhlet; ETOH-P-B: Trunk bark EtOH extract obtained by percolation; ND: Not Determined.

The observed antiplasmodial activity may be attributed to indolomonoterpenoid alkaloids which were isolated previously from the six evaluated species. Indeed, antimalarial in vitro activity was reported for alkaloids isolated from five Aspidosperma species: A. vargasii A. DC., A. desmanthum Benth. (Andrade-Neto et al. 2007), A. pyrifolium Mart. and A. megalocarpon Müll. 
Arg. (Mitaine-Offer et al. 2002) as well as from Geissospermum sericeum (Sagot.) Benth. \& Hook.f. which belongs also to the Apocynaceae family and is used to treat malaria in Brazil, Guiana and Suriname (Steele et al. 2002). We have previously reported on the isolation and identification of alkaloids from $A$. parvifolium (Jácome et al. 2004) and more recently on the antiplasmodial activity of uleine, the major alkaloid from this species. (Oliveira et al. 2010)

Our results seem to confirm the popular use of Aspidosperma species to treat malaria in Brazil and other Central and Southamerican countries. The great chemical diversity of alkaloids from Aspidosperma species (Pereira et al. 2007), the low number of those that were assayed for antiplasmodial activity and the traditional use of several Aspidosperma species to treat malaria/fever turn this investigation of great interest. Bioguided isolation of antiplasmodial compounds from the Aspidosperma species assayed is on progress.

\section{ACKNOWLEDGMENTS}

To Conselho Nacional de Desenvolvimento Científico e Tecnológico (CNPq) and Fundação de Amparo à Pesquisa do Estado de Minas Gerais (FAPEMIG) for financial support Programa de Apoio a Núcleos de Excelências (PRONEX CNPq Process 555655/2009-1 and FAPEMIG Process CDS APQ 01129-10) and research fellowship (CNPq to ABO and MMP). To Dr. J. A. Lombardi for collection and taxonomical identification of the plant species; to Dr. Luzia H. Carvalho, CPqRR/FIOCRUZ, Belo Horizonte, Brazil, for providing the $P$. falciparum clones and for valuable support to Maria Fâni Dolabela during her $\mathrm{PhD}$ work and to Dr. Geraldo Célio Brandão for the cytoxicity assays in Vero cells culture. MFD carried out the reported work as part of her PhD Thesis. ABO was responsible for the phytochemical work that was carried out in the Laboratório de Fitoquímica, Faculdade de Farmácia,
UFMG, Belo Horizonte, Brazil. The other authors have participated in the antiplasmodial bioassays under the supervision of MMP, in the Instituto Evandro Chagas - IEC, PA, Brazil.

\section{RESUMO}

Informações etnomédicas mostram que algumas espécies de Aspidosperma (Apocynaceae) são utilizadas contra a malária no Brasil e motivaram a avaliação de 6 espécies que foram coletadas no Estado de Minas Gerais: A. cylindrocarpon Müll. Arg., A. parvifolium A. DC., A. olivaceum Müll. Arg., A. ramiflorum Müll. Arg., A. spruceanum Benth. ex Müll. Arg. and A. tomentosum Mart. Um total de 23 extratos de diferentes partes das plantas, em diferentes solventes, foram testados in vitro contra cepas de Plasmodium falciparum resistente a cloroquina (W2) e sensível a cloroquina (3D7). Todos os extratos mostraram-se ativos apresentando valores de $\mathrm{CI}_{50}$ na faixa de $5,0 \pm 2,8 \mu \mathrm{g} / \mathrm{mL}$ a $65,0 \pm 4,2 \mu \mathrm{g} /$ $\mathrm{mL}$. O perfil por CCD dos extratos revelou a presença de alcalóides nas 6 espécies avaliadas. Esses resultados parecem confirmar o uso popular de espécies de Aspidosperma no tratamento da malária humana no Brasil e parecem indicar os alcalóides como possíveis compostos ativos das espécies testadas.

Palavras-chave: atividade antimalárica, Plasmodium falciparum, ensaios in vitro, Aspidosperma spp., Apocynaceae.

\section{REFERENCES}

Agripino D, Lima M, Silva M, Meda C, Bolzani V, Cordeiro I, Young M AND MORENO P. 2004. Screening of brazilian plants for antimicrobial and dna-damaging activities. I. Atlantic Rain Forest-Ecological Station Juréia-Itatins. Biota Neotropica 4: 1-15.

ANDRADE-NETO VF ET AL. 2007. In vitro inhibition of Plasmodium falciparum by substances isolated from Amazonian antimalarial plants. Mem Inst Oswaldo Cruz 102: 359-365.

BAGGisH AL AND HILl DR. 2002. Antiparasitic agent atovaquone. Antimicrob Agents Chemother 46: 1163-1173.

BECKER ER. 1949. Report on 35 drugs and three plant materials tested against Plasmodium lophurae in the white Pekin duck. Iowa State Coll J Sci 23: 189-194, apud Mariath et al. 2009. 
BERTANi S, Bourdy G, LANDAU I, RoBINSON JC, ESTERRE E AND DEHARO E. 2005. Evaluation of French Guiana traditional antimalarial remedies. J Ethnopharmacol 98: 45-54.

Boulos M, Dutra AP, DisAnti SM, Shiroma M AND AmATo-Neto V. 1997. Avaliação clínica do quinino para o tratamento da malária por Plasmodium falciparum. Rev Soc Bras Med Trop 30: 211-213.

Bourdy G, Oporto P, Gimenez A And Deharo E. 2004. A search for natural bioactive compounds in Bolivia through a multidisciplinary approach. Part VI. Evaluation of the antimalarial activity of plants used by IsoceñoGuarani Indians. J Ethnopharmacol 93: 269-277.

Bourdy G, Willcox ML, Ginsburg H, Rasoanaivo P, GRAZ B AND DEHARO E. 2007. Ethnopharmacology and malaria: New hypothetical leads or old efficient antimalarials? Intern J Parasitol 38: 33-41.

BRANDÃo MGL, Botelho MGA AND KRettli AU. 1985. Quimioterapia experimental antimalárica com produtos naturais: I. Uma abordagem mais racional?/Experimental antimalarial chemotherapy with natural products: I. A more rational approach? Ciênc Cult 37: 1152-1163.

BRANDÃO MGL, GRANDI TSM, ROCHA EMM, SAWYER DR AND KRETTLI AU. 1992. Survey of medicinal plants used as antimalarials in the Amazon. J Ethnopharmacol 36: 175-182.

CABral JA, McChesney MD AND Milhous WR. 1993. A new antimalarial quassinoid from Simaba guianensis. J Natural Products 56: 1954-1961.

CAmpos AR, Lima Jr RC, UchoA DE, Silveira ER, SANTOS FA AND RAO VS. 2006. Pro-erectile effects of an alkaloidal rich fraction from Aspidosperma ulei root bark in mice. J Ethnopharmacol 104: 240-244.

CARVAlho LH, BRANDÃo MGL, SANTOS-FILHo D, Lopes JLC AND KRETTLI AU. 1991. Antimalarial activity of crude extracts from Brazilian plants studied in vivo in Plasmodium berghei-infected mice and in vitro against Plasmodium falciparum in culture. Brazilian J Med Biol Res 24: 1113-1123.

Castellanos JRG, Prieto JM And Heinrich M. 2009. Red Lapacho (Tabebuia impetiginosa) - A global ethnopharmacological commodity? J Ethnopharmacol 121: 1-13.

CRAGG GM AND NEWMAN DJ. 2005. Plants as sources of anticancer agents. J Ethnopharmacol 100: 72-79.

FERreira DT, SILVA JVJ, SOEIRA LS, ZANOLli LA, ISHIKAWA NK, BABOSA AM AND YASSUMOTO L. 2003. Avaliação da atividade antifúngica dos extratos etanólicos de raiz, caule e folha de Aspidosperma polyneuron. In XI Encontro de Química da Região Sul, Pelotas.

Ferreira IC, LONARdoni MV, MACHAdo GM, LEON LL, GobBi Filho L, Pinto LH AND OliveirA AJ. 2004. Anti-leishmanial activity of alkaloidal extract from Aspidosperma ramiflorum. Mem Inst Oswaldo Cruz 99: 325-327.

Fidock DA, Rosenthal PJ, CROFT L, BRUN R AND NWAKA S. 2004. Antimalarial drug discovery: efficacy models for compound screening. Nature Rev Drug Discovery 3: 509-520.
GinsBURG H AND DeHARO E. 2011. A call for using natural compounds in the development of new antimalarial treatments - an introduction. Malar J 10(Suppl. 1): S1.

Granato D, Nunes DS, Mattos PP, Rios EM, GLinski A, RRIGUES LC AND ZANUSSO Jr G. 2005. Chemical and biological evaluation of rejects from the wood industry. Brazil Arch Biol and Tech 48: 237.

Guerin PJ, Olliaro P, Nosten F, Druilhe P, LAXMINARAYAN R, BINKA F, KILAMA W, FORD N AND White NJ. 2002. Malaria: current status of control, diagnosis, treatment, and a proposed agenda for research and development. Lancet Infect Dis 2: 564-573.

JÁCOME RLRP, OLIVEIRA AB, RASLAN DS AND WAGNER H. 2004. Estudo químico e perfil cromatográfico das cascas de Aspidosperma parvifolium A. DC. ("Pau-Pereira"). Quim Nova 27: 897-900.

Krettli LG, Paula RC, VArotti FP, Pereira MM, Oliveira AJB AND Krettli AU. 2008. Antimalarial activity of extracts from Aspidosperma plants tested in vitro against Plasmodium falciparum drug resistant parasites and in animal models. In XXIV Meeting of the SBPz; Águas de Lindoia, São Paulo, 168 p.

Kvist LP, Christensen SB, Rasmussen HB, MeJia K AND GONZALEZ A. 2006. Identification and evaluation of Peruvian plants used to treat malaria and leishmaniasis. J Ethnopharmacol 106: 390-402.

MARCONDES-FERREIRA NeTO WM. 1988. Aspidosperma Mart. nom. cons. Apocynaceae: estudos taxonômicos. Tese de Doutorado. Universidade de Campinas. Campinas, SP, Brasil.

MARIATH IR, FALCÃO HS, BARBOSA-FILHO JM, SOUSA LCF, TOMAZ ACAT, BATISTA LM, Diniz MFFM, ATHAYDEFilho PF, TAVARES JF AND CUNHA EVL. 2009. Plants of the American continent with antimalarial activity. Rev Brasil Farmacognosia 19: 158-192.

Mesquita ML, Grellier P, Mambu L, Paula JE AND ESPINDOLA LS. 2007. In vitro antiplasmodial activity of Brazilian Cerrado plants used as traditional remedies. J Ethnopharmacol 110: 165-170.

MiLliken W AND ALBERT B. 1996. The use of medicinal plants by the Yanomami Indians of Brazil. Econ Bot 50: 10-25.

Milliken W AND AlBert B. 1997. The use of medicinal plants by the Yanomami Indians of Brazil, Part II. Econ Bot 51: 264-278.

Mitaine-Offer AC, Sauvain M, Valentin A, Callapa J, MALLIÉ M AND ZĖCHES-HANROT M. 2002. Antiplasmodial activity of Aspidosperma indole alkaloids. Phytomedicine 9: 142-145.

MS-MINISTÉRIODASAÚDE, BRASIL.2008.http://portal.saude. gov.br/portal/saude/profissional/visualizar_texto.cfm?idtxt= 31086\&janela $=2$ (accessed in January 6, 2012).

Oliveira AB, Dolabela MF, Braga FC, JÁcome LRP, VAROTTI FP AND PÓvoA MM. 2009a. Plantderived antimalarial agents: new leads and efficient phythomedicines. Part I. Alkaloids. An Acad Bras Cienc 81: 715-740. 
Oliveira AB, Dolabela MF, Póvoa MM, SAntos AND CAM AND VAROTII FP. 2010. Antimalarial activity of ulein and proof of its action on the Plasmodium falciparum digestive vacuole. Malar J 9 (Suppl. 2): 9.

OliveIRA VB ET AL. 2009b. Atividade biológica de alcalóides indólicos do gênero Aspidosperma (Apocynaceae): uma revisão. Rev Brasil Plantas Med, Botucatú 11: 92-99.

PEREIRA MM, JÁCOME RLRP, ALACÂNTARA AFC, AlvES RB AND RASLAN DS. 2007. Alcalóides indólicos de espécies do gênero Aspidosperma (Apocynaceae). Quim Nova 30: 970-983.

PEREIRA MM ET AL. 2006. Constituintes químicos e estudo biológico de Aspidosperma nitidum (Apocynaceae). Rev Brasil Pl Med 8: 1-8.

RiecKmann KH, CAmpBel GH, SAX LJ AND Ema JE. 1978. Drug sensitivity of Plasmodium falciparum. An in vitro microtechnique. The Lancet 311(8054): 22-23.

SPERling H, Lorenz A, Krege S, ARndt R AND Michel MC. 2002. An extract from the bark of Aspidosperma quebracho-blanco binds to human penile alphaadrenoceptors. J Urol 168: 160-163.

SteEle JCP, VeITCH NC, KIT GC, Simmonds MSJ AND WARHURST DC. 2002. Indole and $\beta$-caboline alkaloids from Geissospermum sericeum. J Nat Prod 65: 85-88.

TANAKa JC, Silva CC, Ferreira IC, Machado GM, LeON LL AND OLIVEIRA AJ. 2007. Antileishmanial activity of indole alkaloids from Aspidosperma ramiflorum. Phytomedicine 14: 377-380.

Tanaka JC, Silva CC, Oliveira AJ ANd Dias Filho BP. 2006. Antibacterial activity of indole alkaloids from Aspidosperma ramiflorum. Braz J Med Biol Res 39: 387-391.

TRAGER W AND JENSEN JB. 1976. Human malaria parasites in continuous culture. Science 193: 673-675.
TwENTYMAn PR AND Luscombe M. 1987. A study of some variables in a tetrazolium dye (MTT) based assay for cell growth and chemosensitivity. Br J Cancer 56: 279-285.

WAGNER H. 2004. Natural products chemistry and phytomedicine research in the new millennium: new developments and challenges. ARKIVOC (vii): 277-284.

WAGNer H, BladT S AND ZGAINSKI EM. 1944. Plant drug analysis:a thin layer chromatography atlas. Berlin, Springer Verlag, $1^{\text {st }}$ ed., $320 \mathrm{p}$.

WAGNER H AND SEITZ R. 1998. Lapacho (Tabebuia impetiginosa): Poträt einer südamerikanishen Urwalddroge. Zeitschrift für Phytotherapie 19: 226-238.

WASICKY R, UNTI O AND BARBIERI E. 1942. Quinine and alkaloids in Brazil. An Fac Farm Odontol Univ São Paulo 3: 137 apud Mariath et al. 2009.

Weniger B, Robledo S, Arango GJ, Deharo E, Aragon R, Muñoz V, Callapa J, Lobstein A and ANTON R. 2001. Antiprotozoal activities of Colombian plants. J Ethnopharmacol 78: 193-200.

WHO. 2008. WORLD MALARIA REPORT 2008. Geneva, World Health Organization, http://www.who.int/malaria/world malaria_report_2008/en/

WHO. 2009. WORLD MALARIA REPORT 2009. Geneva, World Health Organization, http://www.who.int/malaria/world malaria report 2009/en/

WHO. 2010. WORLD MALARIA REPORT 2010. Geneva, World Health Organization, http://www.who.int/malaria/world malaria_report_2010/en/

WHO. 2011. WORLD MALARIA REPORT 2011. Geneva, World Health Organization, http://www.who.int/malaria/world malaria_report_2011/en/

Wright CW. 2005. Plant derived antimalarial agents: New leads and challenges. Phytochem Rev 4: 55-61. 